\title{
Chemical stability vs. isotope changes in ferrous mineral water (Karelia, northwest Russia)
}

\author{
E.YU. YAKOVLEV*1, I.V. TOKAREV ${ }^{2}$, G.S. \\ BORODULINA $^{3}$, I.L. KAMENSKY ${ }^{4}$ AND V.I. SKIBA ${ }^{4}$ \\ ${ }^{1}$ N. Laverov Federal Center for Integrated Arctic Research of \\ UB RAS, Arkhangelsk (*yakovlev.iepn@gmail.com) \\ ${ }^{2}$ St. Petersburg State University, St. Petersburg \\ ${ }^{3}$ Karelian Research Centre of RAS, Petrozavodsk \\ ${ }^{4}$ Kola Science Centre of RAS, Apatity
}

Groundwater with high concentration of iron ion $\left(\mathrm{Fe}^{2+}\right)$ is widespread on northwest region of Russia, and since 1719 there is unique health resort of ferrous mineral water, which exploited by 4 wells. Total mineralization of water in wells vary from 0.3 to $0.9 \mathrm{~g} / 1$ with averages $\mathrm{pH}=6.0-6.3$, $\mathrm{Fe}^{2+}=14-106 \mathrm{mg} / \mathrm{l}, \mathrm{Ca}^{2+}+\mathrm{Mg}^{2+}=40-105 \mathrm{mg} / \mathrm{l}, \mathrm{SO}_{4}{ }^{2-}=76-$ $430 \mathrm{mg} / 1, \mathrm{HCO}_{3}^{-}=100-124 \mathrm{mg} / 1, \mathrm{CO}_{2}=90-340 \mathrm{mg} / \mathrm{l}$, which are stable in long-term scale for each well. Chemical composition of water, stable isotopes $\left(\delta^{2} \mathrm{H}, \delta^{18} \mathrm{O}\right)$, tritium $\left({ }^{3} \mathrm{H}\right)$, disequilibrium uranium $\left({ }^{234} \mathrm{U} /{ }^{238} \mathrm{U}\right)$, and noble gases $\left({ }^{3} \mathrm{He} /{ }^{4} \mathrm{He},{ }^{20} \mathrm{Ne} /{ }^{4} \mathrm{He}\right)$ are measured in $1979,1980,1989$, and after 2005 regularly at the same time or separately.

Noble gases $\left({ }^{3} \mathrm{He} /{ }^{4} \mathrm{He}=1.36-1.56\right.$ and ${ }^{20} \mathrm{Ne} /{ }^{4} \mathrm{He}=2.04$ 2.69 in 1989 , and ${ }^{3} \mathrm{He} /{ }^{4} \mathrm{He}=1.44-2.27$ and ${ }^{20} \mathrm{Ne} /{ }^{4} \mathrm{He}=2.38-$ 3.33 in 2013) and tritium $\left({ }^{3} \mathrm{H}=11.3-27.9 \mathrm{TU}\right.$ in 1989 and ${ }^{3} \mathrm{H}=2-7 \mathrm{TU}$ in 2013) point at mixing of young and old components. The tritium/helium-3 age of the young component was $\sim 34$ years (1989) and $\sim 45$ years (2013). Abundance of "old" waters between the two tests decreased. In $1979 \delta^{2} \mathrm{H}, \delta^{18} \mathrm{O}$ were significantly shifted right from Local Meteoric Line and turn to modern precipitations between 1980 and 2005. Bottom layer of peat bog, in which mineral water intakes, has ${ }^{14} \mathrm{C}$ age about $9.5 \mathrm{ka}\left(\delta^{13} \mathrm{C}=-23 \%\right.$ PDB in 1979 and $\delta^{13} \mathrm{C}=-8.5 \ldots-15.5 \%$ in 2005). Uranium has isotope ratio ${ }^{234} \mathrm{U} /{ }^{238} \mathrm{U}$ is 1.37 in lowest part, 2.21 in middle part and $1.57\left({ }^{234} \mathrm{U} /{ }^{238} \mathrm{U}=3-4\right.$ in 1979 and ${ }^{234} \mathrm{U} /{ }^{238} \mathrm{U}=0.78$ 1.51 in modern water) in surface layer of peat bog.

Chemical composition of water is stable in contrast to isotope tracers. Cation $\mathrm{Fe}^{2+}$ and anion $\mathrm{SO}_{4}{ }^{2-}$ are still major components and total mineralization is not significantly vary on perennial scale. It seems melanterite from water-bearing rocks are main factor of water chemistry, but genesis of solvent is strongly depends from climate conditions. In particular, thawed water from permafrost was general component of mineral water in middle of Holocene.

The study was supported by RFBR project 18-45-100004 and by the grant of the President of Russian Federation for young scientists MK-1919.2020.5. 